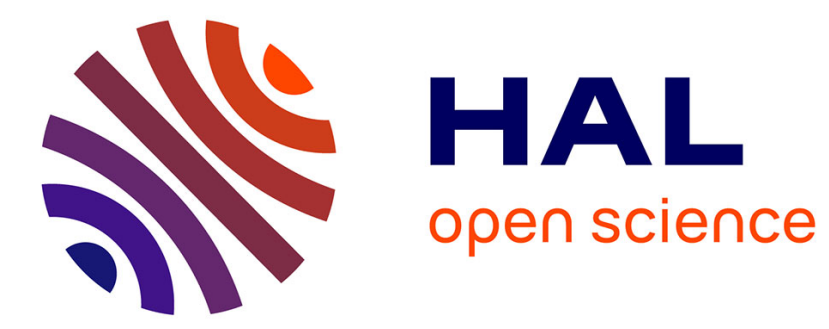

\title{
PROGRESS IN APPLYING STABLE ATOMIC HYDROGEN METHODS TO POLARIZED PROTON SOURCES AND JETS
}

D. Kleppner

\section{- To cite this version:}

D. Kleppner. PROGRESS IN APPLYING STABLE ATOMIC HYDROGEN METHODS TO POLARIZED PROTON SOURCES AND JETS. Journal de Physique Colloques, 1985, 46 (C2), pp.C2665-C2-667. 10.1051/jphyscol:1985283 . jpa-00224602

\section{HAL Id: jpa-00224602 https://hal.science/jpa-00224602}

Submitted on 1 Jan 1985

HAL is a multi-disciplinary open access archive for the deposit and dissemination of scientific research documents, whether they are published or not. The documents may come from teaching and research institutions in France or abroad, or from public or private research centers.
L'archive ouverte pluridisciplinaire HAL, est destinée au dépôt et à la diffusion de documents scientifiques de niveau recherche, publiés ou non, émanant des établissements d'enseignement et de recherche français ou étrangers, des laboratoires publics ou privés. 
JOURNAL DE PHYSIQUE

Colloque C2, supplément au n², Tome 46, février 1985

page C2-665

PROGRESS IN APPLYING STABLE ATOMIC HYDROGEN METHODS TO POLARIZED PROTON SOURCES AND JETS

D. Kleppner

Department of Physics and Research Laboratory of Electronics, Massachusetts Institute of Technology, Cambridge, Massachusetts 02139, U.S.A.

Résumé - Nous résumons brièvement les progrès obtenus par l'utilisation de techniques de polarisation de l'hydrogène atomique pour produire des protons polarisés.

Abstract - Progress in using spin-polarized hydrogen techniques to produce polarized protons is briefly summarized.

The possibilities of applying the techniques of spin-polarized atomic hydrogen (Ht) to provide polarized protons for application in particle and nuclear physics were recognized soon after the creation of spin-polarized hydrogen $/ 1,2 /$. The basic science of $\mathrm{H} \downarrow$ has been described in a recent review article /3/, and various experimental approaches have been described in previous conferences $/ 4,5 /$. This brief account summarizes work in progress toward practical polarized proton jets and sources.

T. Ni inikoski and his colleagues at CERN have produced $\mathrm{H} \downarrow$ in an apparatus adapted from a dynamically polarized proton target, shown in Fig. 1. Atomic hydrogen enters via a Tefion tube (PTFE tube) and passes through a thermalizing region where it is cooled to approximately 0.3K. Atoms in the "down" electron spin state are magnetically attracted to the liquid helium-lined chamber in the stabilization solenoid; atoms in the "up" state are repelled. By using microwave radiation to drive an electron spin flip transition, atoms in a selected hyperfine state are ejected, forming an intense polarized atomic beam which can be used for a polarized proton source or target.

H has been created and studied in this apparatus with the exit window sealed, i.e., in a "closed" geometry. Tests are in progress on the "open" cell geometry. The principle challenge in an open cell is to control the superfiuid $\mathrm{He}$ film which is needed to prevent hydrogen recombination on the walls. The film naturally flows to high temperature areas, and can cause a thermal short circuit. This problem is avoided by film burners which evaporate the film and allow it to condense in a region of high refrigeration power. This system is currently under test.

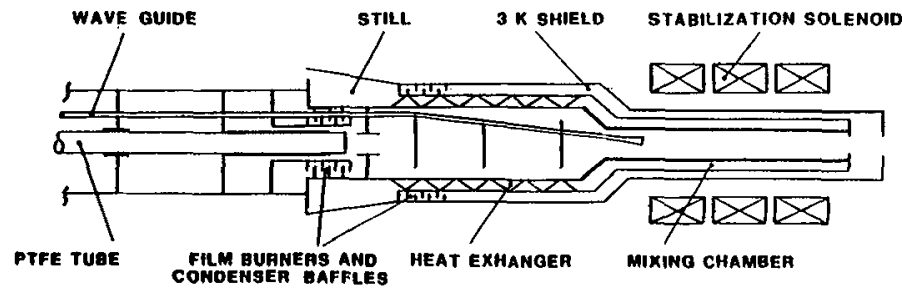

Fig. 1. Spin-polarized hydrogen apparatus in use at CERN. Courtesy of T.O. Niinikoski. 
A polarized proton jet is under design and construction by the university of Michigan Polarized Proton Group, in collaboration with the Spin-Polarized Hydrogen Group at M.I.T.. and Brookhaven National Laboratory. The design goal is a column density at the jet's focus of $10^{14}$ particles $\mathrm{cm}^{-2}$. Operation will be pulsed with a period of $2.5 \mathrm{~s}$, and a duty cycle of $10 \%$. The cryostat, refrigerator and storage cell are shown in Fig. 2 .

The realization of polarized sources and jets involves such considerations as the design of beam optics /5/, transport, relaxation and recombination processes within the storage cell, and the design of an efficient microwave system. Work on these will be reported elsewhere.

Work at M.I.T. is sponsored by the Department of Energy, Grant DEAC02-76ET03069.

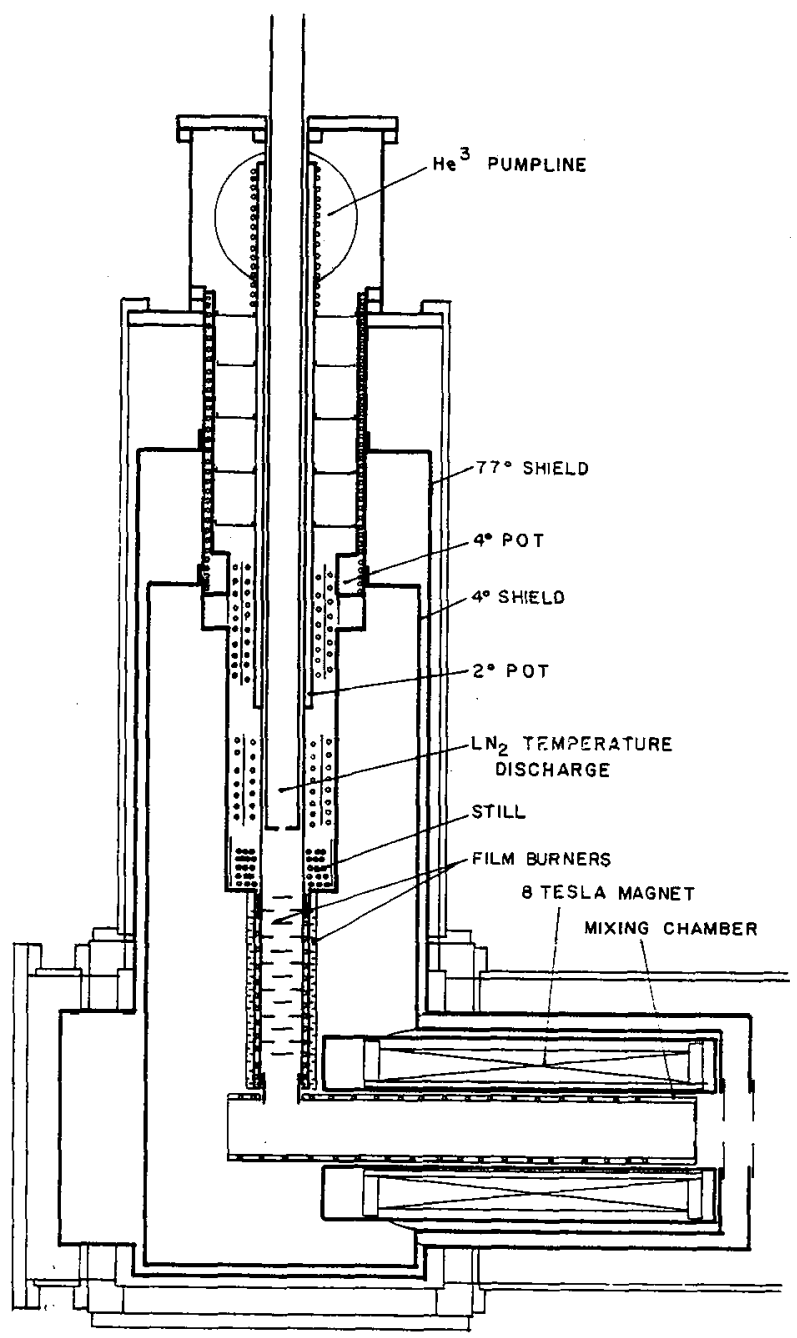

Fig. 2. Spin-polarized hydrogen polarized proton jet under construction by the Michigan-MITBrookhaven collaboration. Courtesy of the University of Michigan Polarized Proton Group. 


\section{References}

1. NIINIKOSKI, T.O., Proc. Int. Symp. on High-Energy Physics with Polarized Beams and Polarized Targets, Lausanne, 1980 (EXS 38, Birkhauser Verlag, Basle and Stuttgart, 1981), p. 191.

2. KLEPPNER, D., Polarized Proton Ion Sources, (Ann Arbor, 1981); ed., A.D. Krisch and A.T.M. Lin, American Institute of Physics Conference Proceedings No. 80, (1982), p. 111.

3. GREYTAK, T.J. and KLEPPNER, D., New Trends in Atomic Physics, (Les Houches, 1982), G. Grynberg and R. Starace, Ed., N. Holland, 1984 , p. 1127 .

4. KLEPPNER, D. and GREYTAK, T.J., High Energy Spin Physics, (Brookhaven 1982), ed., G.M. Bunce, American Institute of Physics Conference Proceedings, o. 95, (1983), p. 546.

5. KLEPPNER, D., Proceedings of the Third International Symposium on the Production and Neutralization of Negative Ions and Beams, Brookhaven National Laboratory, Nov. 14-18, 1983; to be published. 